\title{
AC 2010-2150: HOW AND WHAT MATHEMATICAL CONTENT IS TAUGHT AND USED BY ENGINEER'S STUDENTS AT THEIR FINAL COURSE PROJECT?
}

\section{Gisela Gomes, Universidade Presbiteriana Mackenzie}

Dr. Gisela Hernandes Gomes is professor and researcher of Mathematics in the Engineering School at Mackenzie Presbyterian University, São Paulo, Brazil.

\section{Janete Bolite Frant, Universidade Bandeirante}

Dr. Janete Bolite Frant is professor and researcher of Mathematics Education at Universidade Bandeirante do Brasil (UNIBAN), São Paulo, Brazil.

\section{Arthur Powell, Rutgers University}

Dr. Arthur B. Powell, Jr. is Associate Professor of Mathematics Education in the Department of Urban Education at the Newark campus of Rutgers University, New Jersey, and Faculty Research Scientist and Associate Director of the Robert B. Davis Institute for Learning of the Graduate School of Education in New Brunswick. 


\title{
How and What Mathematical Content is Taught and Used by Engineering Students in their Final Course Project?
}

\begin{abstract}
The purpose of this research was to investigate the transition from academic mathematics to real-life, engineering situations. In particular, through a case study, we investigate what mathematics content Brazilian undergraduate engineering students at private university use in order to develop their final course project. Theoretically, we use aspects of mathematical thinking raised in the literature reviewed. The methodological approach includes phases of grounded theory. Data collection included students' written documents as well as videotaped interviews with students and their professors.

Results revealed that to accomplish their projects students relied engaged in mathematical modeling and used specific software. Moreover, students showed that they were able to cope with mathematical situations that were not taught in their engineering courses.
\end{abstract}

\section{Introduction}

\section{Mathematics as a service subject - Math in engineering courses}

The question of what mathematics should be taught in undergraduate engineering courses is nowadays a concern of both engineering education researchers and professors of engineering. This concern is evident in recent professional conferences and research studies, in Brazil and abroad. For instance, the American Society for Engineering Education (ASEE) and the Société Européenne pour la Formation des Ingénieurs (SEFI) have devoted considerable attention to engineering education. In Brazil, the Program for Engineering Development (PRODENGE) and the Brazilian Association of the Engineering Education (ABENGE) have sponsored conferences and debates on engineering education.

It is important to note, however, attention to the education of engineers in mathematics have been a topic of concern for mathematics educators, professors and researchers since the creation of the International Commission on Mathematical Instruction (ICMI) in 1908. Even before, in 1907, topical discussions occurred between mathematicians and engineers at the Chicago Symposium on Mathematics for Engineering Students. The following has been the recurring question of these meetings: What mathematics should be taught to engineering students? This question still deserves attention nowadays.

The essential tension that this question raises was outlined in 1912 by White ${ }^{1}$ in Cambridge at the V International Congress of Mathematicians. In his paper, he discussed the role of mathematics for the practice of engineering. He emphasized that a distinction between the professionals of two branches of knowledge: on the one hand, mathematicians teach engineering students using a scientific point of view, building theories and rules relevant to the practice of engineering; on the other hand, engineers 
endowed with good mathematical skills are concerned primarily with the design, durability, and efficiency of a construction. He observed further that collaboration between mathematicians and engineers could lead to better engineering practice.

The debate continues but in an ever-changing global environment of technological advances. In November 2009, the first International Congress of Mathematics, Engineering and Society ( ${ }^{\text {st }}$ ICMES 2009) aimed to bring together mathematicians, engineers, industry professionals and educationalists interested in reflecting on the mathematics used by engineers that could help them to address new technological realities and societal challenges in a more complex and globalized world. The conference focused on the links among mathematics, engineering, and society and proposed to be a permanent forum to discuss the pedagogical aspects of mathematics in engineering curriculum and to reevaluate the mathematics education of engineering students.

It is therefore appropriate to investigate further the educational background of engineers, both in terms of mathematical knowledge acquired in engineering courses and its application in professional activities. Such investigations will contribute to improving the teaching of mathematics in university engineering programs.

\section{Engineering Courses in Brazil and in this particular case study}

In Brazil, the Ministry of Education (MEC) oversees engineering programs and each engineering program consists of ten semesters, either from February to July or August to December. MEC's National Curriculum Guidelines for the Undergraduate Course in Engineering established that engineering programs should aim to provide future professionals with three essential abilities: to apply mathematical, scientific, technological and instrumental knowledge to Engineering; to design and conduct experiments and interpret their results; and to identify, formulate and solve engineering problems.

In 1995, Brazilian government concerned with the teaching for engineering sponsored a project named PRODENGE - Program for Engineering Development. This program that aimed to support engineering programs at universities and the basic subjects such as Physics, Chemistry, Computing and Mathematics promoted the restructuring and modernizing of teaching and research in Engineering (Longo, Rocha and Loureiro ${ }^{2}$ ). It was a partnership of the Coordination for Improving University Education Staff (CAPES), the Secretariat of University Education (SESU) and the National Council of Scientific and Technological Development (CNPq). The results of this effort, according to Longo ${ }^{3}$, should be measured not only by products generated by laboratories, educational material available, published articles, and so forth but also by the important consequences for the formation of Brazilian engineers and the optimization of existing resources for engineering research.

In addition, the Resolution of the National Council of Education's 11th Comission on Higher Education ${ }^{4}$ (CNE-CES 11) establishes that graduate engineering programs, regardless of their modality, must contain the following: 
1) a core of basic courses such as Differential and Integral Calculus, Linear Algebra, Mechanics of Solids, and Introduction to Computers for Engineering,

2) a core of professional courses, and

3) a core of specialized courses that characterize the modality and constitute extensions and deepening of the professional courses.

These materials should be distributed according as illustrated in graph 1 .

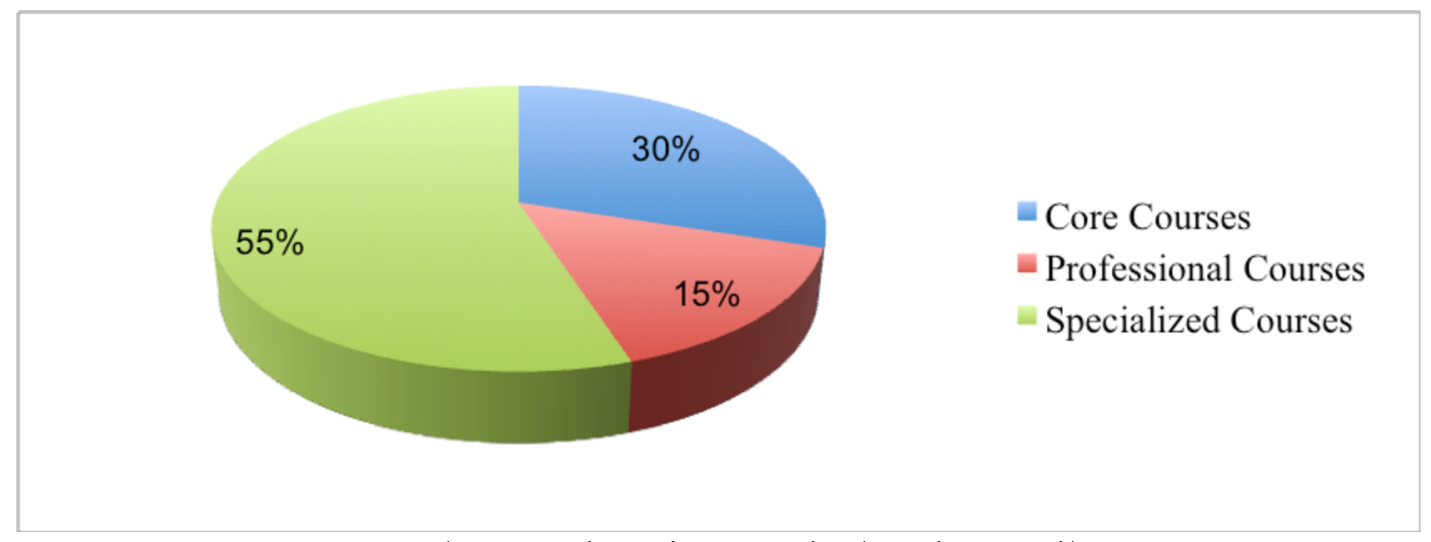

Graph 1: Engineering Curriculum in Brazil

Being that although our focus is on the students' mathematics final course project, it was important to know better how the supervisors worked as well.

\section{Method}

According to Feagin, Orum and Sloberg ${ }^{5}$ a case study is an ideal methodology when a holistic, in-depth investigation is needed. Case study research excels at bringing us to an understanding of a complex issue or object and can extend experience or add strength to what is already known through previous research. Case studies emphasize detailed contextual analysis of a limited number of events or conditions and their relationships. Researchers have used the case study research method for many years across a variety of disciplines. Social scientists, in particular, have made wide use of this qualitative research method to examine contemporary real-life situations and provide the basis for the application of ideas and extension of methods. Researcher $\mathrm{Yin}^{6}$ defines the case study research method as an empirical inquiry that investigates a contemporary phenomenon within its real-life context, and multiple sources of evidence are used.

Our case study examines the mathematical skills that undergraduate engineering students use to accomplish their final course project. To better understand and investigate our problem, we also undertook a grounded theory (GT) approach (Charmaz ${ }^{7}$, Corbin and Strauss ${ }^{8}$ ). The main feature of GT is that it proposes systematic but flexible directions for data collection and a set of systematic, rigorous procedures for data analysis.

The first phase of the interview consisted in defining our research questions that evolved from open questions to a more focus ones. A first interview was held with the 
two professors. The two chosen professors for this investigation are members of the School of Engineering of a private university in the city of São Paulo. One of the professors has an undergraduate degree in mathematics, a master's degree in Engineering and Special Technologies, and a doctorate in Mechanical Engineering. The other professor's undergraduate, master's, and doctoral degrees are all in Mechanical Engineering.

After analyzing this interview we developed questions for a second interview with the same professors to discuss the two final projects that they choose.

After analyzing both interviews holistically we went to a second phase. We analyze different Engineer courses syllabus, with particular care for the two courses revealed in the first two interviews - Mechanic and Industrial Engineer - to better understand the context professors and students were immersed in. Then we decided to look deep into two different projects from two students, since they began developing it up to their final projects, looking at written materials and interviewing each of them. The data, written, video and audio material, were coded in categories while being analyzed. So, partial and final analysis were done while the study progressed and at the end of it.

To conduct the first interview, we outlined a questionnaire that aimed to clarify how the National Guidance for the final course project (FCP) was understood by these professors. Also we would like to raise some aspects of mathematical thinking addressed by Schoenfeld ${ }^{9}$ that could emerge in their discourse while supervising students' FCP. Elements that these professors valued and, consequently could influence their students on how and which Mathematics to be used in their projects.

\section{Results}

The topics originally proposed for the interview were:

- Training (academic and professional) for each teacher;

- Orientation of FCPs (how was handled this approach);

- Use the FCPs of the contents studied over the course of Engineering;

- Difficulties that the teachers interviewed perceived the students to develop and produce their FCPs;

- Means proposed by teachers and used by students in FCPs.

For our second interview and subsequent discussion of FCP, Professor P1 chose the work of a student of Industrial Engineering that aimed to develop a system based on neural networks to analyze and forecast the index of the Stock Exchange of São Paulo; and Professor P2 chose the work of a student of Mechanical Engineering that aimed to analyze four types of parts with different geometries of aggravating tension, using formulas from literature and comparing them with those obtained from calculations made with the aid of computer simulation. 
The second phase, included syllabus review and interviews, revealed that calculus, linear algebra and statistics were among the disciplines every engineer student have in their first years of studying. Other disciplines are introduced by the third year; they are more related to the specific engineering chosen by the students.

Regarding aspects of mathematical thinking the table below revealed the aspects students emphasized in their work and interviews.

\begin{tabular}{|l|l|l|}
\hline $\begin{array}{l}\text { Aspects of mathematical } \\
\text { thinking }\end{array}$ & Student 1 & Student 2 \\
\hline Knowledge base & $\begin{array}{l}\text { Linear regression; } \\
\text { equations; graphs of } \\
\text { functions }\end{array}$ & $\begin{array}{l}\text { Matrix; Gauss method for } \\
\text { equations; geometry; } \\
\text { concept of variables }\end{array}$ \\
\hline Problem solving strategy & $\begin{array}{l}\text { Raise conjectures; } \\
\text { verify conjectures and } \\
\text { refine if it would be the } \\
\text { case. } \\
\text { Compare old and new } \\
\text { data in order to check a } \\
\text { computer software } \\
\text { developed by the } \\
\text { student }\end{array}$ & $\begin{array}{l}\text { Raise conjectures; verify } \\
\text { would be the case. } \\
\text { Refining the problem; }\end{array}$ \\
\hline Use of resources & $\begin{array}{l}\text { Matlab and Minitab; } \\
\text { textbooks }\end{array}$ & $\begin{array}{l}\text { Software tutorials; text } \\
\text { books; Ansys }\end{array}$ \\
\hline Beliefs and feelings & $\begin{array}{l}\text { Problems that figure on } \\
\text { textbooks are far from } \\
\text { real problems in daily } \\
\text { life. }\end{array}$ & $\begin{array}{l}\text { Mathematics is only a } \\
\text { tool. } \\
\text { School Mathematics does } \\
\text { not work and is not } \\
\text { applicable to daily life. }\end{array}$ \\
\hline Mathematical practice & $\begin{array}{l}\text { Modeling; estimating, } \\
\text { uncertainty reasoning. }\end{array}$ & $\begin{array}{l}\text { Modeling, estimating, } \\
\text { uncertainty, visualization. }\end{array}$ \\
\hline
\end{tabular}

Table 1: Aspects of mathematical thinking found in the work of students 1 and 2.

These elements describe how the two engineering students employed mathematical thinking in the development and elaboration of their FCPs.

Upon developing a system based on the neural networks to analyze and forecast the indices of the stock market, Student 1 used her knowledge of statistics and interpretation of graphs to compare results obtained with Matlab software and those found using regression analysis. The model of the problem permitted her to explain other aspects of practical mathematics: estimation.

In his FCP, Student 2 modeled the problem in which he analyzed four different types of geometric figures that required him to focus on various aspects of mathematical thinking. In addition, for Student 2 to understand the problem that he had to solve, with his advisor's help, he constructed a simpler model, using a problem-solving strategy, 
named by Cardella ${ }^{10}$ as transforming the problem.

It is noteworthy that two different FCPs, from different areas of Engineering, some aspects of mathematical thinking were common in the development and elaboration of the FCPs. Modeling and estimation appear in both FCPs, which seem to suggest that they are common mathematical practices in Engineering.

\section{Final Considerations}

It is worth noting that even though different jobs in different branches of engineering require different mathematical skills, some aspects of mathematical thought revealed to be common during the development of these FCP. The modelling and estimating strategies appear in both FCPs and suggest that they are mathematical practices common to the practice of engineers. It will be interesting to further this investigation by studying to the extent to which this practice is explicitly taught in the core mathematics courses.

Another important and complex factor about engineering course problems appeared in students' interviews. The beliefs evident in the statements of two students, which, though expressed differently, support the finding of Schoenfeld" that "the mathematics learned in school has little or nothing to do with real world".

It will be important to further research about those beliefs because although stated by the students in this case study that the "School Mathematics is not applicable to daily life" both of them were able to cope with a real engineer problem using the mathematical skills they learned during their course.

\section{Bibliography}

1 White, H. W. (1912) The fifth International Congress of Mathematicians. Bulletin of the American Mathematical Society. 19(3), 124-129.

2 Longo, W. P., Rocha, I., Loureiro, L. V. (1996). The Brazilian National Program for Engineering Development: Prodenge. Proceedings of the World Congress of Engineering Education Industry Leaders, 485-500. Recuperado em 25 agosto, 2007, de http://www.waldimir.longo.nom.br/artigos/63.doc

3 Longo, W. P. (2004). O programa de desenvolvimento de engenharias. Revista Brasileira de Inovação, 3(2), 417-447.

4 National Council of Education's 11th Comission on Higher Education. Diário Oficial da União. (11 ${ }^{\text {th }}$ Mar, 2002). Retrieved July 18, 2007, from http://portal.mec.gov.br/cne/arquivos/pdf/CES112002.pdf

5 Feagin, J., Orum, A., Sjoberg, G. (Eds.), (1991). A case for case study. Chapel Hill, NC: University of North Carolina Press.

$6 \quad$ Yin, R. K. (1984). Case study research: Design and methods. Newbury Park, CA: Sage

7 Charmaz, K. (2006). Constructing Grounded Theory: a practical guide through qualitative analysis. Thousand Oaks, CA, USA: Sage.

8 Corbin, J. M., Strauss, A. L. (2008). Basics of qualitative research: techniques and procedures for developing Grounded Theory. Thousand Oaks, CA, USA: Sage Publications. 
9 Schoenfeld, A. H. (1992). Learning to think mathematically: problem solving, metacognition, and sense-making in mathematics. In D. Grouws (Ed.), Handbook for research on mathematics teaching and learning (pp. 334-370). New York: MacMillan.

10 Cardella, M. (2006). Engineering Mathematics: an Investigation of students' mathematical thinking from a cognitive engineering perspective. [Doctoral dissertation]. University of Washington: Seattle, WA. 